Article

\title{
Steady-State Investigation of Carbon-Based Adsorbent-Adsorbate Pairs for Heat Transformation Application
}

\author{
Faizan Shabir ${ }^{1,2}$, Muhammad Sultan ${ }^{1, *(1)}$, Yasir Niaz ${ }^{2}$, Muhammad Usman ${ }^{3, *(1)}$, \\ Sobhy M. Ibrahim ${ }^{4}$, Yongqiang Feng ${ }^{5}$, Bukke Kiran Naik ${ }^{6}\left(\mathbb{0}\right.$, Abdul Nasir $^{7}$ and Imran Ali ${ }^{8}$ \\ 1 Department of Agricultural Engineering, Bahauddin Zakariya University, Multan 60800, Pakistan; \\ faizan.shabir@kfueit.edu.pk \\ 2 Department of Agricultural Engineering, Khwaja Fareed University of Engineering \& \\ Information Technology, Rahim Yar Khan 64200, Pakistan; yasir.niaz@kfueit.edu.pk \\ 3 Institute for Water Resources and Water Supply, Hamburg University of Technology, \\ Am Schwarzenberg-Campus 3, 20173 Hamburg, Germany \\ 4 Department of Biochemistry, College of Science, King Saud University, P.O. Box 2455, Riyadh 11451, \\ Saudi Arabia; syakout@ksu.edu.sa \\ 5 School of Energy and Power Engineering, Jiangsu University, Zhenjiang 212013, China; yqfeng@ujs.edu.cn \\ 6 Department of Mechanical Engineering, National Institute of Technology Rourkela, Odisha 769008, India; \\ naikkb@nitrkl.ac.in \\ 7 Department of Structures and Environmental Engineering, University of Agriculture, Faisalabad 38000, \\ Pakistan; anawan@uaf.edu.pk \\ 8 Department of Environmental Science and Engineering, College of Chemistry and \\ Environmental Engineering, Shenzhen University, Shenzhen 518060, China; engrimran56@gmail.com \\ * Correspondence: muhammadsultan@bzu.edu.pk (M.S.); muhammad.usman@tuhh.de (M.U.); \\ Tel.: +92-333-610-8888 (M.S.); Fax: +92-61-9210298 (M.S.)
}

Received: 27 July 2020; Accepted: 26 August 2020; Published: 28 August 2020

\begin{abstract}
In this study, the ideal adsorption cycle behavior of eight activated carbon and refrigerant pairs is evaluated. The selected pairs are KOH6-PR/ethanol, WPT-AC/ethanol, Maxsorb-III/methanol, Maxsorb-III/CO ${ }_{2}$, Maxsorb-III/n-butane, Maxsorb-III/R-134a, SAC-2/R32 and Maxsorb-III/R507a. The following cooling performance parameters are evaluated for all pairs: specific cooling energy (SCE), concentration difference $(\Delta \mathrm{W})$ and coefficient of performance $(\mathrm{COP})$ of ideal adsorption cooling and refrigeration cycles. The evaporator temperatures for the applications of adsorption cooling and refrigeration are selected as 7 and $-5^{\circ} \mathrm{C}$, respectively. It is found that the Maxsorb-III/methanol pair has shown the highest specific cooling energy and coefficient of performance in a wide range of desorption temperatures; i.e., for the adsorption cooling cycle it has SCE and COP of $639.83 \mathrm{~kJ} / \mathrm{kg}$ and 0.803 , respectively, with desorption temperatures of $80^{\circ} \mathrm{C}$. The KOH6-PR/ethanol and the WPT-AC/ethanol pairs also give good performances comparable to that of the Maxsorb-III/methanol pair. However, the SAC-2/R32 pair possesses a higher concentration difference than the Maxsorb-III/methanol, KOH6-PR/ethanol and WPT-AC/ethanol pairs but shows a lower performance. This is due to the lower isosteric heat of adsorption of SAC-2/R32 compared to these pairs. It is found that Maxsorb-III/methanol, KOH6-PR/ethanol and WPT-AC/ethanol are the most promising pairs for application in designing adsorption cooling and refrigeration systems.
\end{abstract}

Keywords: adsorbent; adsorbate; cooling; refrigeration; performance; ideal cycle analysis 


\section{Introduction}

The demands for air conditioning and refrigeration are growing extensively with the progression of the quality of living and human thermal comfort [1,2]. Vapor-compression systems are mostly used in daily life to meet these demands because of their compactness in design and a high coefficient of performance. However, most of these systems utilize harmful refrigerants, which possess high global warming and ozone depletion potentials [3]. The conventional vapor-compression systems heavily consume electrical resources and have a prominent dependence on the grid in the summer season. For this reason, the load on the grid can be substantially reduced by using renewable energy resources for cooling or air-conditioning purposes. In this regard, thermally driven air-conditioning and refrigeration systems are gaining attention from researchers in order to provide a sustainable and environmentally friendly solution. Such systems include adsorption [4-6], absorption [7-9] and desiccant [10-12] technologies.

Thermally driven adsorption cooling systems primarily consist of sorption beds (for adsorption and desorption), condensers, expansion valves and evaporators, as shown in Figure 1a. The adsorption cooling cycle begins with the adsorption of refrigerant onto the sorption bed by allowing the entry of the low-pressure refrigerant. Heat rejected during the adsorption process is dissipated by the cooling water cycle. This process continues until the sorption bed becomes entirely saturated with refrigerant. Later, the sorption bed is disconnected from the condenser and the evaporator. It is then put into desorption mode by supplying heat through a hot water cycle. The condenser is connected to the sorption bed and allows the refrigerant to enter at high pressure. At that point, the refrigerant continues to pass through the expansion valve to complete the cycle. In Figure $1 \mathrm{~b}$, the ideal adsorption cycle in Dühring's diagram represents the four processes. First is the isosteric heating/preheating process ( 1 to 2). Second is the isobaric heating/desorption process (2 to 3). Third is the isosteric cooling/precooling process ( 3 to 4 ). Fourth is the isobaric cooling/adsorption process (4 to 1). The first and third processes of heating and cooling take place at a constant uptake, while the second and fourth processes of adsorption and desorption are isobaric. Since heat is released and added during the adsorption and desorption processes, it requires external cooling and heating cycles to maintain the inlet cooling and hot water temperatures, respectively.

Adsorption cooling units are thermally driven systems which may be powered by solar radiation or low-grade waste heat from various sources $[13,14]$. At present, the performance of these systems is lower as compared to vapor-compression systems. Much work has been done to commercialize the adsorption refrigeration system. New and improved sorption bed design [15,16], multibed strategies [17-20] and hybrid adsorption cooling systems [21-24] have also been implemented for performance enhancement. The initial development in this regard took the form of silica-gel/water-based adsorption refrigeration units $[25,26]$. These units could not penetrate the market due to their large ecological footprints, high maintenance requirement (because of their operation under vacuum conditions) and low coefficient of performance (COP). Many studies have been conducted for pressurized adsorption systems employing these refrigerants, i.e., ethanol, methanol, R-134a and R-32, which have a lower triple point temperature to achieve a lower cooling temperature [27-30]. Concerning refrigerants, a lot of effort has been made towards the development of new adsorbent materials [31-34] and the study of their interactions with various refrigerants under a wide range of operating pressures. A good adsorbent must have [35,36] (i) a large adsorption uptake at a relatively low temperature, (ii) a lower specific heat capacity, (iii) an ability to desorb the refrigerant completely under desorption conditions, (iv) a high thermal conductivity, (v) less deterioration of adsorbent with time and (vi) a low cost. Some important adsorbents are activated carbons [37,38], silica gel [39,40], metal-organic frameworks [41,42] and composite adsorbents [43,44].

In our previous study, carbon-based adsorbents were found to be more effective adsorbents in terms of high adsorption capacities and surface area [45]. Some of these are Maxsorb-III, spherical activated carbons (SAC), activated carbon charcoal and activated carbon fiber (ACF). In this study, an ideal cycle thermodynamic analysis of activated carbon and refrigerant pairs is performed for the evaluation 
of an efficient adsorption cooling and refrigeration system. The evaporator temperatures for the adsorption cooling and refrigeration cycles are fixed at 7 and $-5{ }^{\circ} \mathrm{C}$, respectively, while the desorption temperatures range from 60 to $100^{\circ} \mathrm{C}$. The performance of these cycles is evaluated in terms of specific cooling effect (SCE) and coefficient of performance (COP).

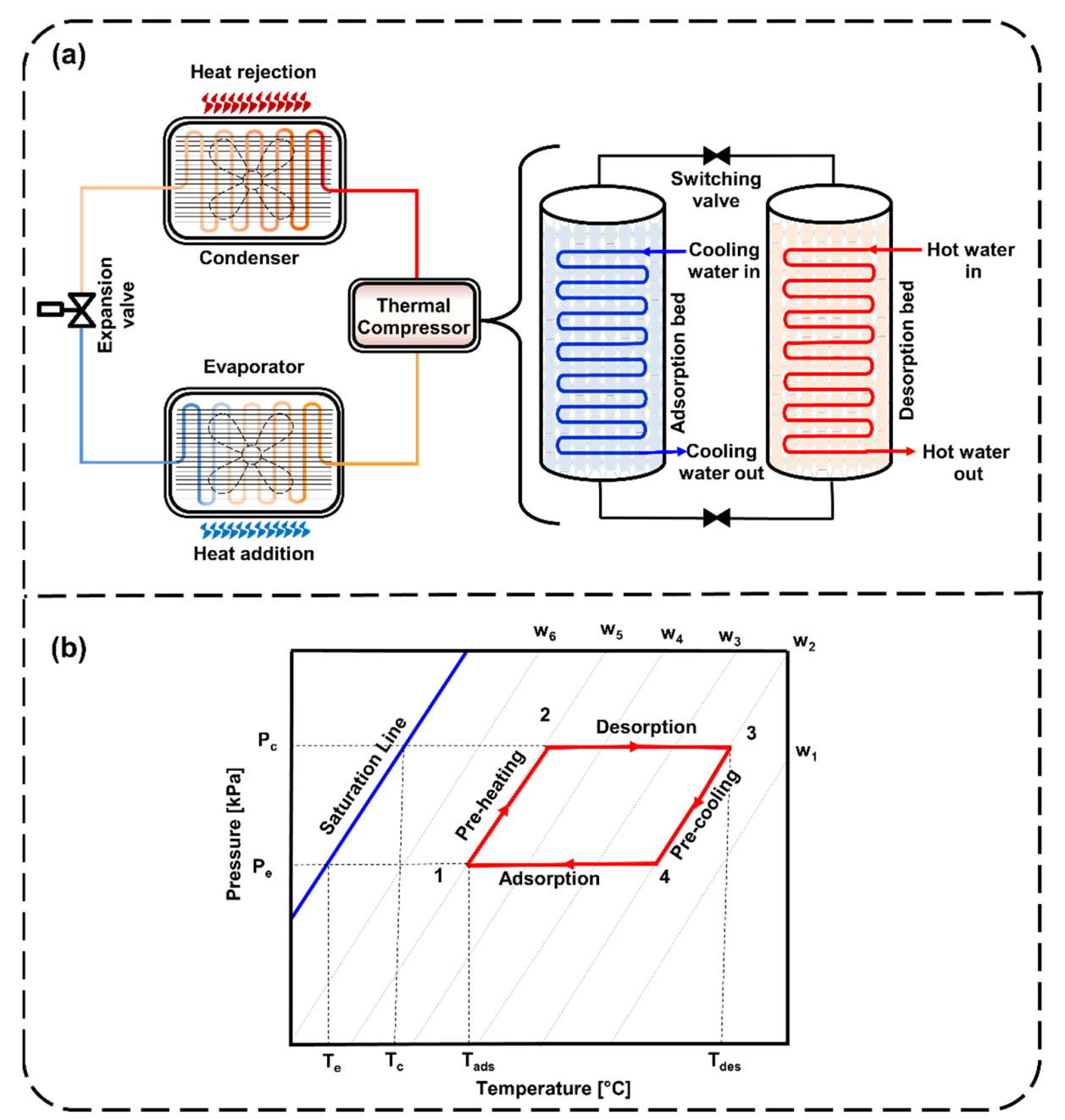

Figure 1. Demonstration of (a) a typical adsorption cooling/refrigeration system and (b) the Dühring diagram with idealized adsorption cooling/refrigeration cycles.

\section{Materials and Methods}

\subsection{Adsorbent-Adsorbate Pairs}

In our previous study, carbon-based adsorbents were found to be more effective adsorbents in terms of their high surface area and adsorption capacities [45]. Therefore, in this study, activated carbon (AC) adsorbents paired with different refrigerants were selected for the calculation of the idealized cooling and refrigeration cycles. The KOH6-PR/ethanol [46], WPT-AC/ethanol [47], Maxsorb-III/methanol [48], Maxsorb-III/CO 2 [49], Maxsorb-III/n-butane [50], Maxsorb-III/R-134a [51], SAC-2/R32 [52] and Maxsorb-III/R507a [51] adsorbent-refrigerant pairs were selected. These specific pairs were selected based on their higher adsorption capacities when compared to other pairs of AC adsorbents with the same refrigerant. 


\subsection{Adsorption Equilibrium Models}

The Dubinin-Astakhov (D-A) [53,54] and Dubinin-Radushkevich (D-R) [55] adsorption isotherm models were used for modeling the adsorption isotherms. The D-A (Equation (1)) and D-R (Equation (2)) isotherm model equations are given as follows:

$$
\begin{aligned}
& W=W_{o} \exp \left\{-\left(\frac{A}{E}\right)^{n}\right\} \\
& W=W_{o} \exp \left\{-\left(\frac{A}{E}\right)^{2}\right\}
\end{aligned}
$$

where $\mathrm{W}$ and $\mathrm{W}_{\mathrm{o}}$ are equilibrium and maximum adsorption uptake, respectively. $\mathrm{E}, \mathrm{A}$ and $\mathrm{n}$ represent the characteristic energy, adsorption potential and the structural heterogeneity parameter, respectively. The difference between Equations (1) and (2) is the value of $n$. When this value is equal to 2, it represents the D-R adsorption isotherm model. The fitting parameters of these equations for the assorted pairs are given in Table 1. The adsorption potential (A) can be further calculated by using Equation (3):

$$
\mathrm{A}=\mathrm{RT} \ln \left(\frac{\mathrm{P}_{\mathrm{s}}}{\mathrm{P}}\right)
$$

where $\mathrm{P}$ and $\mathrm{P}_{\mathrm{s}}$ are the equilibrium and saturated pressures, respectively. $\mathrm{T}$ is the adsorption temperature, and $\mathrm{R}$ is the gas constant. If the adsorption amount is in the volumetric adsorption amount $\left(\mathrm{q}\left(\mathrm{cm}^{3} / \mathrm{g}\right)\right)$, it can be converted into the equilibrium adsorption amount $(\mathrm{W}[\mathrm{kg} / \mathrm{kg}])$ by Equation (4) as $\mathrm{q}=\mathrm{W} \mathrm{V}_{\mathrm{m}}$.

$$
\mathrm{W}=\frac{\mathrm{W}_{\mathrm{o}}}{\mathrm{V}_{\mathrm{m}}} \exp \left\{-\left(\frac{\mathrm{A}}{\mathrm{E}}\right)^{\mathrm{n}}\right\}
$$

$\mathrm{V}_{\mathrm{m}}$ is the molar volume, which can be calculated by Equation (5):

$$
\mathrm{V}_{\mathrm{m}}=\mathrm{V}_{\mathrm{t}} \exp \left(\alpha\left(\mathrm{T}-\mathrm{T}_{\mathrm{t}}\right)\right)
$$

where $V_{t}$ is the molar volume of the refrigerant at triple point temperature $\left(T_{t}\right)$, and $\alpha$ is the thermal expansion coefficient. If adsorption temperature is greater than the refrigerant's critical temperature $\left(\mathrm{T}_{\mathrm{cr}}\right)$, then the saturated pressure $\left(\mathrm{P}_{\mathrm{s}}\right)$ that corresponds to that adsorption temperature can be calculated by pseudo-saturated vapor pressure (see Equation (6)) [56].

$$
\left(\frac{\mathrm{P}_{\mathrm{s}}}{\mathrm{P}_{\mathrm{cr}}}\right)=\left(\frac{\mathrm{T}}{\mathrm{T}_{\mathrm{cr}}}\right)^{\mathrm{k}}
$$

where $\mathrm{P}_{\mathrm{cr}}$ is the critical pressure of the refrigerant and $\mathrm{k}$ is the fitting constant.

Table 1. Isotherm model parameters of D-A equation of selected adsorbent-refrigerant pairs.

\begin{tabular}{cccccc}
\hline Adsorbent-Refrigerant Pairs & $\mathbf{W}_{\mathbf{o}} / \mathbf{q} \mathbf{o}$ & $\mathbf{E}(\mathbf{k J} / \mathbf{k g})$ & $\mathbf{n}(-)$ & $\mathbf{k}(-)$ & References \\
\hline KOH-6-PR/ethanol & $1.98(\mathrm{~kg} / \mathrm{kg})$ & 90 & 1.5 & - & {$[46]$} \\
\hline WPT-AC/ethanol & $1.9(\mathrm{~kg} / \mathrm{kg})$ & 91.55 & 1.43 & - & {$[47]$} \\
\hline Maxsorb-III/methanol & $1.24(\mathrm{~kg} / \mathrm{kg})$ & 129.28 & 2 & - & {$[48]$} \\
\hline Maxsorb-III/CO 2 & $1.5408\left(\mathrm{~cm}^{3} / \mathrm{g}\right)$ & 119.39 & 1.326 & 4.504 & {$[49]$} \\
\hline Maxsorb-III/n-butane & $0.8(\mathrm{~kg} / \mathrm{kg})$ & 300 & 1.02 & - & {$[50]$} \\
\hline Maxsorb-III/134a & $2.2(\mathrm{~kg} / \mathrm{kg})$ & 87.25 & 1.29 & - & {$[51]$} \\
\hline SAC-2/R32 & $3.1344(\mathrm{~cm} / \mathrm{g})$ & 67.24 & 1.0217 & 3.65 & {$[52]$} \\
\hline Maxsorb-III/507a & $2.05(\mathrm{~kg} / \mathrm{kg})$ & 76.34 & 1.34 & - & {$[51]$} \\
\hline
\end{tabular}




\subsection{Steady-State Model for SCE and COP}

A Dühring or P-T-W (pressure-temperature-concentration) diagram depicting the ideal adsorption cooling and refrigeration cycles of the assorted pairs was constructed. The adsorption cooling and refrigeration cycle performance was evaluated by a time-independent model. The thermodynamic framework for the ideal cycle analysis is discussed in Equation (7) to Equation (11). The specific cooling effect (SCE) can be evaluated as given in Equation (7):

$$
\operatorname{SCE}=\left(W_{\max }-W_{\min }\right)\left[L_{T_{e}}-\int_{T_{e}}^{T_{c}} C_{P_{\text {ref }}} d T\right]
$$

where $W_{\max }$ and $W_{\min }$ are the maximum and minimum adsorption uptake, respectively. The $C_{P_{\text {ref }}}$ is the specific heat capacity of the refrigerant. $\mathrm{Th}_{\mathrm{LH}}$ is the vaporization enthalpy at evaporator temperature $\left(T_{e}\right)$. The heat added to the adsorbent $\left(Q_{a d s}\right)$ is calculated by Equation (5) as seen below.

$$
\mathrm{Q}_{\mathrm{ads}}=\int_{\mathrm{T}_{1}}^{\mathrm{T}_{3}} \mathrm{C}_{\mathrm{P}_{\mathrm{ads}}} \mathrm{dT}
$$

where $C_{P_{\text {ads }}}$ represents the specific heat capacity of the adsorbent. The values of the heat capacities of the selected adsorbents can be found elsewhere $[57,58]$. The total heat added to the refrigerant $\left(\mathrm{Q}_{\mathrm{ref}}\right)$ is calculated by Equation (9).

$$
Q_{\text {ref }}=W_{\max } \int_{T_{1}}^{T_{2}} C_{P_{\text {ref }}} d T+\int_{T_{2}}^{T_{3}} W \cdot C_{P_{\text {ref }}} d T+\int_{W_{\min }}^{\mathrm{W}_{\max }} Q_{s t} d W
$$

In Equation (9), the first and the second terms express the sensible heat added to the refrigerant during the preheating and desorption processes. The last term represents the latent heat added. Since the heat is released and added during the adsorption (4-1) and desorption (2-3) processes, it requires external cooling and heating cycles to maintain the inlet cool and hot water temperatures, respectively. Due to the idealization and simplification of the model, these heats cannot be computed. However, both are important for economic analysis. The coefficient of performance (COP) of the system can be calculated by Equation (10):

$$
\mathrm{COP}=\frac{\mathrm{SCE}}{\mathrm{Q}_{\mathrm{ads}+} \mathrm{Q}_{\mathrm{ref}}}
$$

\subsection{Isosteric Heat of Adsorption}

Isosteric heat of adsorption $\left(\mathrm{Q}_{\mathrm{st}}\right)$ of the assorted pairs is evaluated by the Clausius-Clapeyron equation (see Equation (11). The adsorption isotherm data are incorporated for the calculation of $Q_{s t}$. The Clausius-Clapeyron equation is given below.

$$
\frac{\mathrm{Q}_{\mathrm{st}}}{\mathrm{R}}=\left[\frac{\partial \ln \mathrm{P}}{\partial(1 / \mathrm{T})}\right]_{\mathrm{W}}
$$

\section{Results and Discussion}

Figures 2 and 3 represent the P-T-W diagrams of all assorted pairs. These diagrams are formed by utilizing the adsorption isotherm model parameters as furnished in Table 1 . The equilibrium pressure is evaluated for the constant uptake (isosters) at various adsorption temperatures $\left(0-100^{\circ} \mathrm{C}\right)$. Thus, the different isosteric lines for the range between initial and saturation line uptakes are 
calculated. The ideal adsorption cooling and refrigeration cycles are also drawn on the same P-T-W diagrams. The ideal adsorption cycle processes (1-2-3-4) are presented in these diagrams, making it possible to determine the efficiency of the cycles. Both cycles are operative between two isotherms, i.e., the adsorption temperature of $30{ }^{\circ} \mathrm{C}$ and the desorption temperature of $80^{\circ} \mathrm{C}$. The cycles work between the pressure limits of evaporator pressure $\left(\mathrm{P}_{\mathrm{e}}\right)$ and condenser pressure $\left(\mathrm{P}_{\mathrm{c}}\right)$. Evaporator temperature $\left(\mathrm{T}_{\mathrm{e}}\right)$ for the adsorption cooling and refrigeration cycles is fixed at 7 and $-5{ }^{\circ} \mathrm{C}$, respectively.

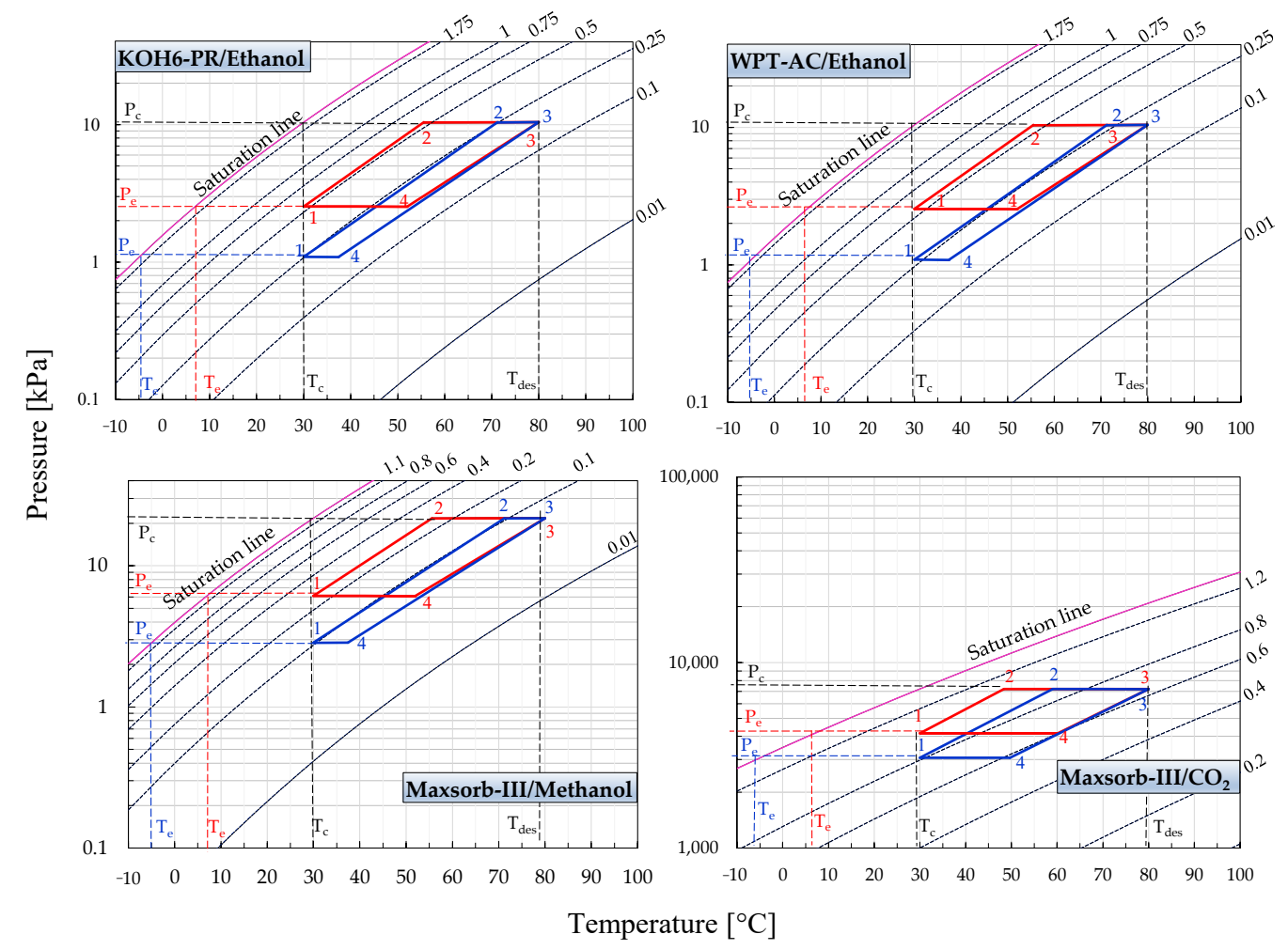

Figure 2. Pressure-temperature-concentration (P-T-W) diagrams of KOH6-PR/ethanol, WPT-AC/ ethanol, Maxsorb-III/methanol and Maxsorb-III/CO $/ \mathrm{CO}_{2}$ pairs presenting the ideal (red line) adsorption cooling cycle $\left(\mathrm{T}_{\mathrm{e}}=7^{\circ} \mathrm{C}\right)$ and (blue line) adsorption refrigeration cycle $\left(\mathrm{T}_{\mathrm{e}}=-5^{\circ} \mathrm{C}\right)$ for a desorption temperature of $80^{\circ} \mathrm{C}$.

The isosteric heat of adsorption is evaluated for all selected pairs using the Clausius-Clapeyron equation (see Equation (11)). The isosteric lines of different constant uptakes (from initial to saturated uptakes) are developed by linear plot between $\ln P$ and 1/T. The $Q_{\text {st }}$ values are calculated from the slope of each isosteric line. The average values of $Q_{s t}$ from these plots are used for the calculation of $\mathrm{Q}_{\text {ref }}$ (see Equation (9)). A plot of isosteric heat of adsorption vs. adsorption uptakes is presented in Figure 4. The adsorption uptake is taken in percentage, which is the ratio of equilibrium uptake to saturated adsorption uptake. Isosteric heat of adsorption decreases with the increase in adsorption uptake, as reported in many studies [32,59].

The concentration difference $(\Delta W)$ is the difference between the maximum $\left(W_{\max }\right)$ and minimum $\left(\mathrm{W}_{\min }\right)$ adsorption uptake of the ideal adsorption cycle. It is noteworthy that $\mathrm{W}_{\max }$ corresponds to the refrigerant's adsorption uptake at adsorption temperature and evaporator pressure. $W_{\min }$ is the adsorption uptake by the refrigerant at desorption temperature and condenser pressure. For a higher performance of the ideal cycle, the adsorbent-refrigerant pair should exchange a large amount of $\Delta \mathrm{W}$. A comparison of $\Delta \mathrm{W}$ between the assorted pairs at various desorption temperatures $\left(80,90\right.$ and $\left.100^{\circ} \mathrm{C}\right)$ for cooling $\left(\mathrm{T}_{\mathrm{e}}=7^{\circ} \mathrm{C}\right)$ and refrigeration $\left(\mathrm{T}_{\mathrm{e}}=-5^{\circ} \mathrm{C}\right)$ applications is shown in Figure 5. The SAC-2/R32 pair possesses the highest value of $\Delta \mathrm{W}$ among the selected pairs for both evaporator temperatures of 7 
and $-5{ }^{\circ} \mathrm{C}$ at all ranges of desorption temperature. The Maxsorb-III/n-butane working pair shows the lowest value of $\Delta \mathrm{W}$.

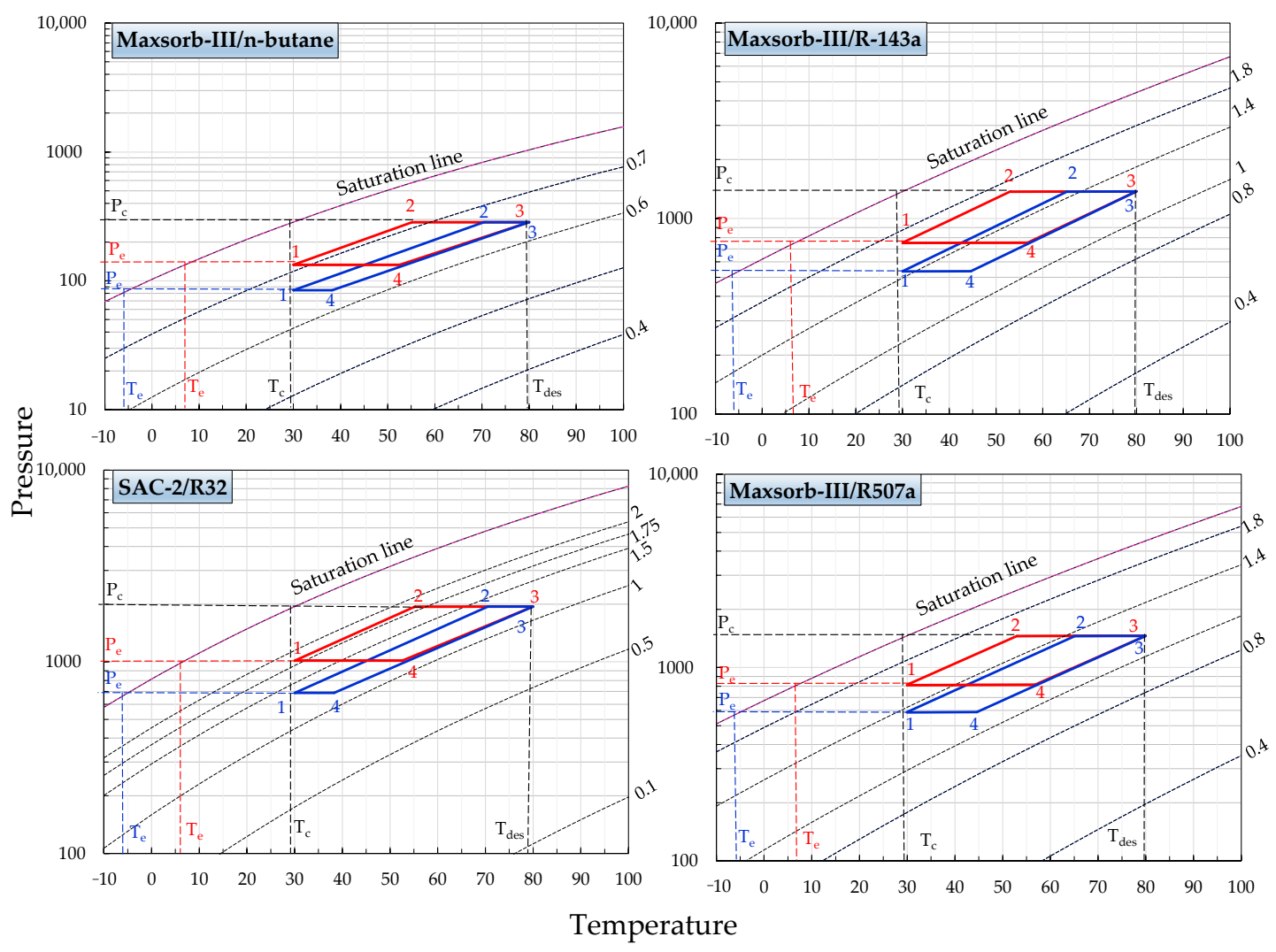

Figure 3. P-T-W diagrams of Maxsorb-III/n-butane, Maxsorb-III/R-134a, SAC-2/R32 and Maxsorb-III/ R507a pairs presenting the ideal (red line) adsorption cooling cycle $\left(\mathrm{T}_{\mathrm{e}}=7^{\circ} \mathrm{C}\right)$ and (blue line) adsorption refrigeration cycle $\left(\mathrm{T}_{\mathrm{e}}=-5^{\circ} \mathrm{C}\right)$ for a desorption temperature of $80^{\circ} \mathrm{C}$.

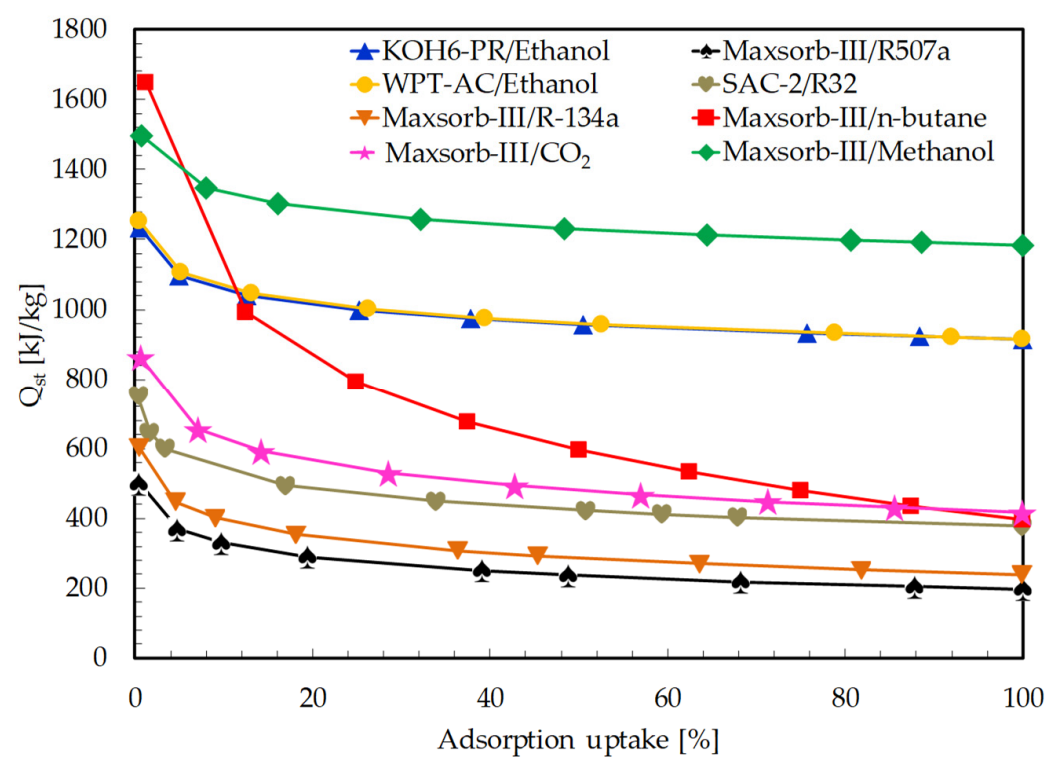

Figure 4. Comparison of isosteric heat of adsorption $\left(\mathrm{Q}_{\mathrm{st}}\right)$ for the assorted pairs as a function of adsorption uptake. 

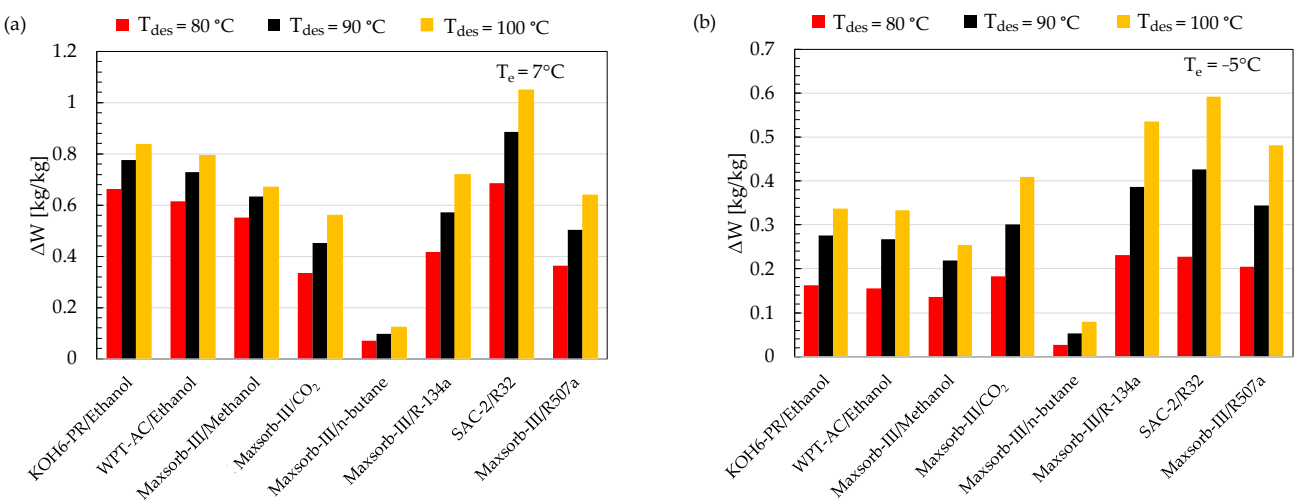

Figure 5. Comparison of $\Delta \mathrm{W}$ for the assorted pairs at different desorption temperatures for (a) cooling $\left(\mathrm{T}_{\mathrm{e}}=7^{\circ} \mathrm{C}\right)$ and $(\mathbf{b})$ refrigeration $\left(\mathrm{T}_{\mathrm{e}}=-5^{\circ} \mathrm{C}\right)$ applications.

The ideal cycle performances of adsorption cooling and refrigeration cycles are evaluated for the evaporator temperatures of 7 and $-5{ }^{\circ} \mathrm{C}$ with a desorption temperature of $80{ }^{\circ} \mathrm{C}$. Among the assorted adsorbent-refrigerant pairs, the Maxsorb-III/methanol pair gives the highest values of specific cooling effect (SCE $=639.83 \mathrm{~kJ} / \mathrm{kg}$ ) and coefficient of performance (COP $=0.803$ ) for the adsorption cooling cycle $\left(\mathrm{T}_{\mathrm{e}}=7^{\circ} \mathrm{C}\right)$ at a desorption temperature of $80^{\circ} \mathrm{C}$ (see Figures 6 and 7). These results are in agreement with the results of [48]. The KOH6-PR/ethanol pair and the WPT-AC/ethanol pair also perform well. However, the lowest performing pair in terms of SCE and COP is the Maxsorb-III/n-butane pair. The SAC-2/R32 pair has the highest $\Delta W$, but it shows a lower performance than the Maxsorb-III/methanol, KOH6-PR/ethanol and WPT-AC/ethanol pairs due to a lower $\mathrm{Q}_{\text {st }}$ value.

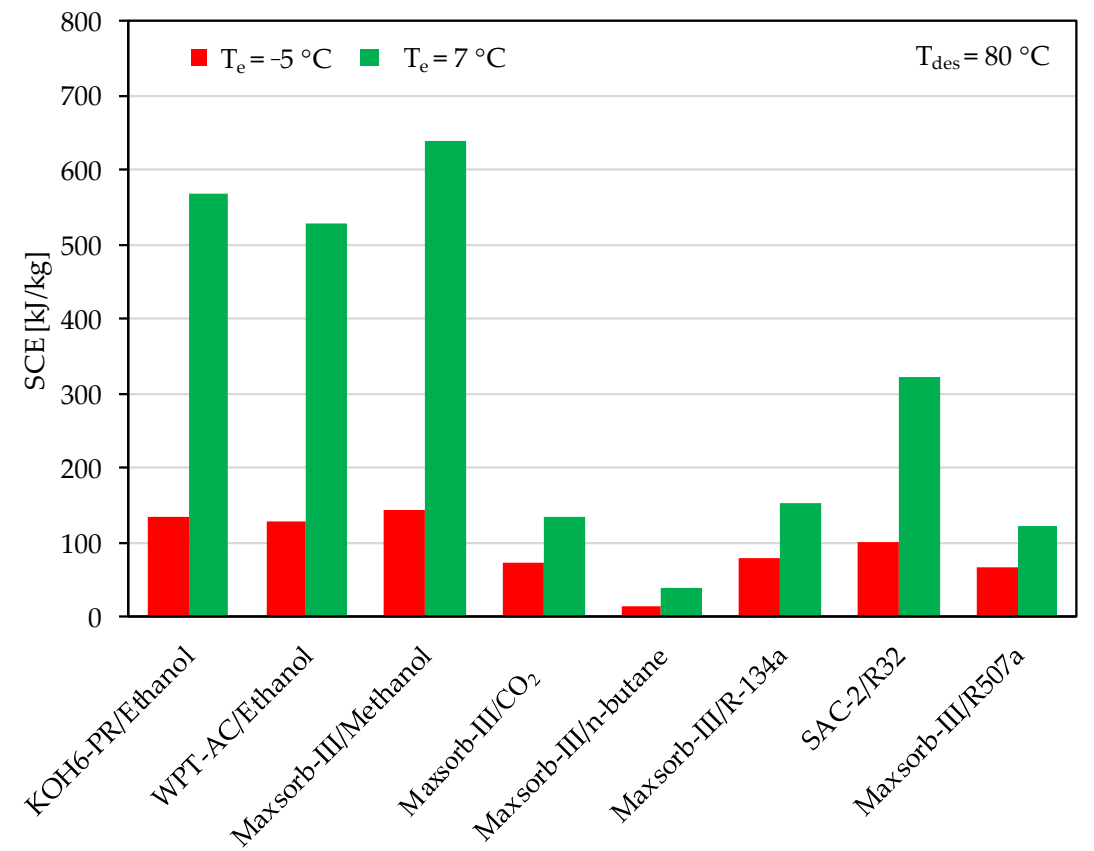

Figure 6. Comparison of specific cooling effect (SCE) between the assorted pairs at a desorption temperature of $80{ }^{\circ} \mathrm{C}$ for adsorption cooling application $\left(\mathrm{T}_{\mathrm{e}}=7^{\circ} \mathrm{C}\right)$ and refrigeration application $\left(\mathrm{T}_{\mathrm{e}}=-5^{\circ} \mathrm{C}\right)$. 


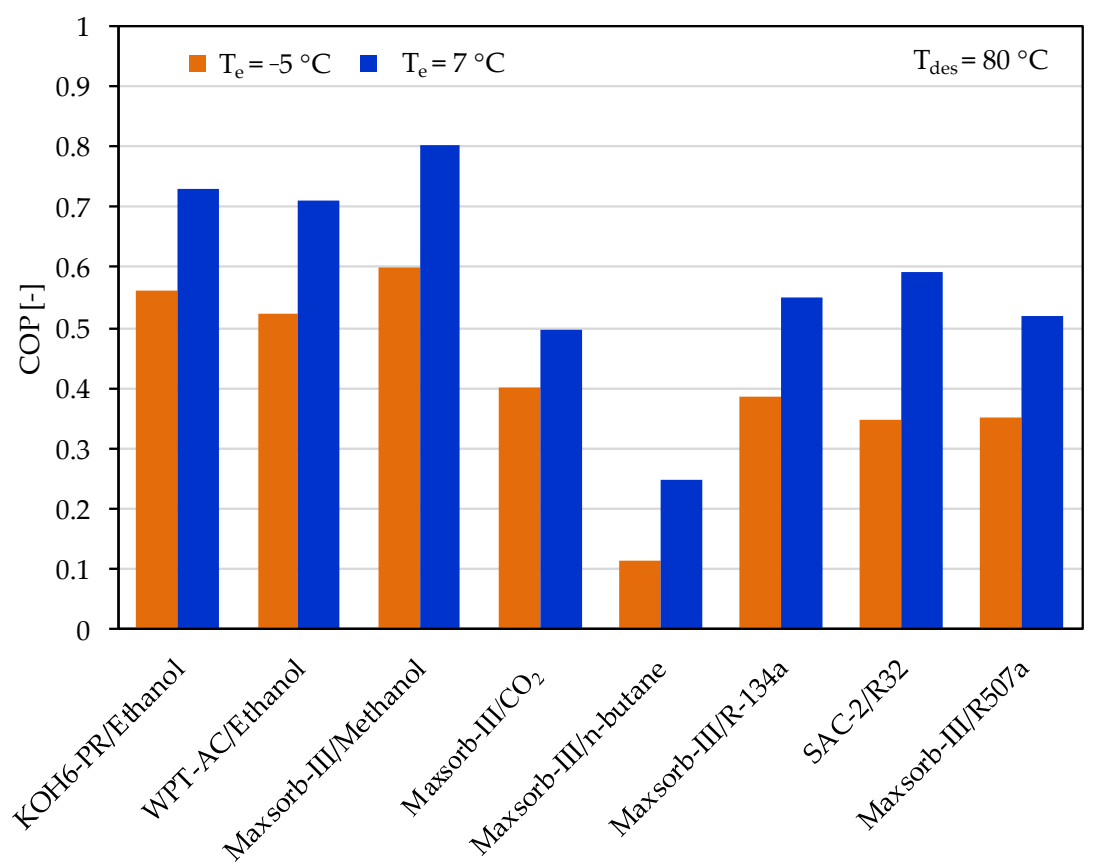

Figure 7. Comparison of the coefficient of performance (COP) between the assorted pairs at a desorption temperature of $80^{\circ} \mathrm{C}$ for adsorption cooling application $\left(\mathrm{T}_{\mathrm{e}}=7^{\circ} \mathrm{C}\right)$ and refrigeration application $\left(\mathrm{T}_{\mathrm{e}}=-5^{\circ} \mathrm{C}\right)$.

The coefficient of performance and the specific cooling effect as a function of desorption temperature for the three most effective pairs (i.e., Maxsorb-III/methanol, KOH6-PR/ethanol and WPT-AC/ethanol) are shown in Figure 8. The specific cooling effect shows a linear relation with the desorption temperature. This is because the concentration difference between adsorption pairs will increase with the increase of desorption temperature for the same evaporator and adsorption temperatures. There is a significant increase in the coefficient of performance for the desorption temperature range from 60 to $80{ }^{\circ} \mathrm{C}$. Subsequently, there is no considerable variation in COP, even though the value of SCE is increasing. This is because the heat input requirement becomes considerably high as the difference between the desorption and the condenser temperatures becomes greater.
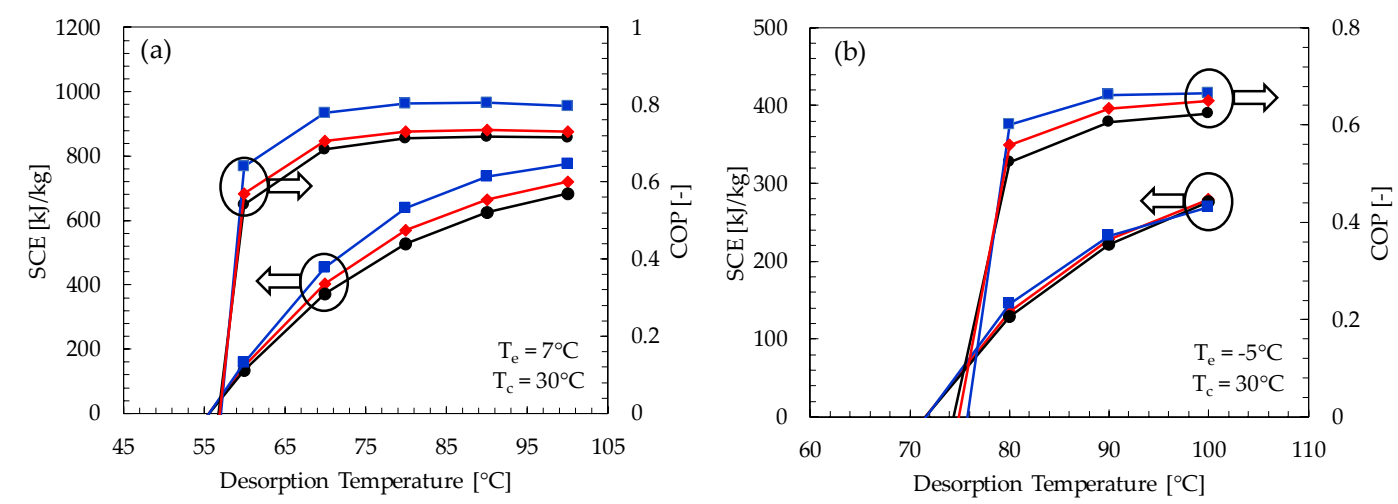

Figure 8. COP and SCE of Maxsorb-III/methanol (blue line), KOH6-PR/ethanol (red line) and WPT-AC/ ethanol (black line) pairs as a function of desorption temperature for (a) adsorption cooling application $\left(\mathrm{T}_{\mathrm{e}}=7^{\circ} \mathrm{C}\right)$ and $(\mathrm{b})$ refrigeration application $\left(\mathrm{T}_{\mathrm{e}}=-5^{\circ} \mathrm{C}\right)$.

It is found that the minimum desorption temperature required by most of the pairs for the adsorption cooling cycle is about $55^{\circ} \mathrm{C}$ at the condenser and adsorption temperature of $30^{\circ} \mathrm{C}$. Similarly, the minimum desorption temperature required for the adsorption refrigeration cycle is about $70^{\circ} \mathrm{C}$. 
The Maxsorb-III/methanol pair is the most promising pair, as it turned out to have maximum COP and SCE for both cooling and refrigeration cycles in all ranges of desorption temperature (see Appendix A Tables A1 and A2). The KOH6-PR/ethanol and the WPT-AC/ethanol pairs also show promising results that are comparable to the Maxsorb-III/methanol pair, as shown in Figure 8.

\section{Conclusions}

The performances of ideal adsorption cooling and refrigeration cycles of AC-based adsorbentrefrigerant pairs are evaluated. Ideal cycle performances of an adsorption system are evaluated for the evaporator temperatures of $7{ }^{\circ} \mathrm{C}$ for cooling and $-5{ }^{\circ} \mathrm{C}$ for refrigeration applications with the desorption temperature range of 60 to $100^{\circ} \mathrm{C}$. The key finding of the study are as follows:

- The Maxsorb-III/methanol pair shows the highest SCE and COP for both cooling and refrigeration cycles at all ranges of desorption temperatures. At a desorption temperature of $80^{\circ} \mathrm{C}$, it has a maximum SCE and COP of $639.83 \mathrm{~kJ} / \mathrm{kg}$ and 0.803 , respectively, for the adsorption cooling cycle. Similarly, for the refrigeration cycle, it shows a SCE and COP of $639.83 \mathrm{~kJ} / \mathrm{kg}$ and 0.803 , respectively.

- The KOH6-PR/ethanol pair also has a good performance, with a SCE and COP of $144.63 \mathrm{~kJ} / \mathrm{kg}$ and 0.601 , respectively, under the same operating conditions.

- The performance-wise sequence of the selected pairs is as follows: Maxsorb-III/methanol > KOH6-PR/ethanol $>$ WPT-AC/ethanol $>$ SAC-2/R32 > Maxsorb-III/R-134a > Maxsorb-III/CO 2 $>$ Maxsorb-III/R507a > Maxsorb-III/n-butane.

- It is found that the minimum desorption temperature required for the adsorption cooling cycle is $55^{\circ} \mathrm{C}$ at the condenser and adsorption temperature of $30^{\circ} \mathrm{C}$. For the adsorption cooling cycle, the minimum desorption temperature required is about $70^{\circ} \mathrm{C}$.

- The SCE shows a linear relation with the desorption temperature. This is due to the increase in concentration difference of adsorption pairs with an increasing desorption temperature.

- There is a significant increase in the coefficient of performance for the desorption temperature range of 60 to $80^{\circ} \mathrm{C}$. Afterwards, no considerable variation in COP is noticeable with an increasing SCE.

- Although the SAC-2/R32 pair has the highest $\Delta W$, it shows a lower performance than Maxsorb-III/methanol, KOH6-PR/ethanol and WPT-AC/ethanol pairs due to a lower $\mathrm{Q}_{\text {st }}$ value compared to these three pairs.

From the study, it is found that Maxsorb-III/methanol, KOH6-PR/ethanol and WPT-AC/ethanol are the most promising pairs for application in the design of adsorption cooling and refrigeration systems.

Author Contributions: Conceptualization, F.S.; Data curation, M.S.; Formal analysis, F.S., M.S., M.U. and B.K.N.; Funding acquisition, M.S., M.U. and S.M.I.; Investigation, F.S. and B.K.N.; Methodology, F.S., Y.F. and B.K.N.; Project administration, M.S. and Y.F.; Resources, Y.N., S.M.I., and A.N.; Software, B.K.N., and I.A.; Supervision, M.S. and Y.F.; Validation, M.S.; Visualization, Y.N., M.U. and S.M.I.; Writing-original draft, F.S. and M.S.; Writing-review \& editing, M.S., Y.N., M.U., S.M.I., Y.F., A.N., and I.A. All authors have read and agreed to the published version of the manuscript.

Funding: This work was supported by Researchers Supporting Project number (RSP-2020/100), King Saud University, Riyadh, Saudi Arabia.

Acknowledgments: This research work has been carried out in the Department of Agricultural Engineering, Bahauddin Zakariya University, Multan, Pakistan. The authors acknowledge the support from the Researchers Supporting Project number (RSP-2020/100), King Saud University, Riyadh, Saudi Arabia. We acknowledge support for the Open Access fees by Hamburg University of Technology (TUHH) in the funding program Open Access Publishing.

Conflicts of Interest: The authors declare no conflict of interest. 


\section{Nomenclature}

$\begin{array}{ll}\text { A } & \text { Adsorption potential }(\mathrm{kJ} / \mathrm{kg}) \\ \text { AC } & \text { Activated carbon } \\ \text { ACF } & \text { Activated carbon fiber } \\ \text { COP } & \text { Coefficient of performance }(-) \\ \mathrm{C}_{\mathrm{p}} & \text { Specific heat capacity }(\mathrm{kJ} /(\mathrm{kg} \cdot \mathrm{K})) \\ \mathrm{D}-\mathrm{A} & \text { Dubinin-Astakhov } \\ \mathrm{D}-\mathrm{R} & \text { Dubinin-Radushkevich } \\ \mathrm{E} & \text { Characteristic energy }(\mathrm{kJ} / \mathrm{mol}) \\ \mathrm{k} & \text { D-A model constant for pseudo-saturated vapor pressure }(-) \\ \mathrm{LH} & \text { Vaporization enthalpy at evaporator temperature }(\mathrm{kJ} / \mathrm{kg}) \\ \mathrm{n} & \text { Structural heterogeneity parameter }(-) \\ \mathrm{P} & \text { Pressure }(\mathrm{kPa}) \\ \mathrm{P}-\mathrm{T}-\mathrm{W} & \text { Pressure-temperature-concentration } \\ \mathrm{q} & \text { Volumetric adsorption amount }\left(\mathrm{cm}^{3} / \mathrm{g}\right) \\ \mathrm{q} & \text { Maximum volumetric adsorption capacity }\left(\mathrm{cm}^{3} / \mathrm{g}\right) \\ \mathrm{Q} & \text { Heat added }(\mathrm{kJ} / \mathrm{kg}) \\ \mathrm{R} & \text { Gas constant }(\mathrm{kJ} /(\mathrm{kg} . \mathrm{K})) \\ \mathrm{SAC} & \text { Spherical activated carbons } \\ \mathrm{SCE} & \text { Specific cooling effect }(\mathrm{kJ} / \mathrm{kg}) \\ \mathrm{T} & \text { Temperature }\left({ }^{\circ} \mathrm{C}\right) \\ \mathrm{V}_{\mathrm{m}} & \text { Molar volume }\left(\mathrm{cm}{ }^{3} / \mathrm{mol}\right) \\ \mathrm{V}_{\mathrm{t}} & \text { Molar volume at triple point temperature }\left(\mathrm{cm}^{3} / \mathrm{mol}\right) \\ \mathrm{W} & \text { Equilibrium adsorption uptake }(\mathrm{kg} / \mathrm{kg}) \\ \mathrm{W} & \text { Maximum adsorption capacity }(\mathrm{kg} / \mathrm{kg}) \\ \Delta \mathrm{W} & \text { Concentration difference }(\mathrm{kg} / \mathrm{kg}) \\ \alpha & \text { Thermal expansion coefficient }\left(\mathrm{K}^{-1}\right) \\ & \end{array}$

\section{Subscripts}

$\begin{array}{ll}\text { ads } & \text { Adsorption } \\ \mathrm{c} & \text { Condenser } \\ \mathrm{cr} & \text { Critical } \\ \mathrm{des} & \text { Desorption } \\ \mathrm{e} & \text { Evaporator } \\ \mathrm{max} & \text { Maximum } \\ \mathrm{min} & \text { Minimum } \\ \text { ref } & \text { Refrigerant } \\ \mathrm{s} & \text { Saturated } \\ \mathrm{st} & \text { Isosteric } \\ \mathrm{t} & \text { Triple point }\end{array}$




\section{Appendix A}

Table A1. Specific cooling energy (SCE) and coefficient of performance (COP) of assorted pairs for evaporator and adsorption temperatures of 7 and $30^{\circ} \mathrm{C}$, respectively.

\begin{tabular}{|c|c|c|c|c|c|c|}
\hline & \multirow{2}{*}{ Adsorbent-Refrigerant Pairs } & \multicolumn{5}{|c|}{ Desorption Temperatures $\left({ }^{\circ} \mathrm{C}\right)$} \\
\hline & & 60 & 70 & 80 & 90 & 100 \\
\hline \multirow{8}{*}{ SCE } & KOH6-PR/ethanol & 147.63 & 404.84 & 569.57 & 666.33 & 719.28 \\
\hline & WPT-AC/ethanol & 134.78 & 372.12 & 529.00 & 625.80 & 682.30 \\
\hline & Maxsorb-III/methanol & 157.57 & 452.55 & 639.83 & 735.79 & 776.28 \\
\hline & Maxsorb-III/ $/ \mathrm{CO}_{2}$ & 34.60 & 85.48 & 135.58 & 183.35 & 227.76 \\
\hline & Maxsorb-III/n-butane & 7.75 & 23.72 & 39.17 & 54.08 & 68.45 \\
\hline & Maxsorb-III/R-134a & 38.13 & 95.06 & 152.52 & 209.06 & 263.59 \\
\hline & SAC-2/R32 & 73.47 & 209.08 & 321.88 & 415.63 & 493.50 \\
\hline & Maxsorb-III/R507a & 30.12 & 76.07 & 123.46 & 170.98 & 217.57 \\
\hline \multirow{8}{*}{$\mathrm{COP}$} & KOH6-PR/ethanol & 0.569 & 0.705 & 0.730 & 0.734 & 0.730 \\
\hline & WPT-AC/ethanol & 0.541 & 0.684 & 0.712 & 0.717 & 0.714 \\
\hline & Maxsorb-III/methanol & 0.639 & 0.779 & 0.803 & 0.804 & 0.797 \\
\hline & Maxsorb-III/CO 2 & 0.336 & 0.452 & 0.497 & 0.519 & 0.533 \\
\hline & Maxsorb-III/n-butane & 0.104 & 0.204 & 0.249 & 0.275 & 0.291 \\
\hline & Maxsorb-III/R-134a & 0.311 & 0.474 & 0.550 & 0.594 & 0.623 \\
\hline & SAC-2/R32 & 0.341 & 0.532 & 0.592 & 0.619 & 0.632 \\
\hline & Maxsorb-III/R507a & 0.273 & 0.436 & 0.519 & 0.570 & 0.604 \\
\hline
\end{tabular}

Table A2. Specific cooling energy (SCE) and coefficient of performance (COP) of assorted pairs for evaporator and adsorption temperatures of -5 and $30^{\circ} \mathrm{C}$, respectively.

\begin{tabular}{|c|c|c|c|c|}
\hline \multirow{2}{*}{ Performance Index } & \multirow{2}{*}{ Adsorbent-Refrigerant Pairs } & \multicolumn{3}{|c|}{ Desorption Temperatures $\left({ }^{\circ} \mathrm{C}\right)$} \\
\hline & & 80 & 90 & 100 \\
\hline \multirow{8}{*}{ SCE } & KOH6-PR/ethanol & 134.83 & 228.13 & 279.19 \\
\hline & WPT-AC/ethanol & 128.76 & 222.10 & 276.58 \\
\hline & Maxsorb-III/methanol & 144.63 & 232.52 & 269.60 \\
\hline & Maxsorb-III/CO $\mathrm{CO}_{2}$ & 73.98 & 121.46 & 165.59 \\
\hline & Maxsorb-III/n-butane & 13.70 & 27.58 & 40.96 \\
\hline & Maxsorb-III/R-134a & 80.50 & 134.14 & 185.88 \\
\hline & SAC-2/R32 & 100.81 & 189.37 & 262.94 \\
\hline & Maxsorb-III/R507a & 65.86 & 110.80 & 154.87 \\
\hline \multirow{8}{*}{$\mathrm{COP}$} & KOH6-PR/ethanol & 0.559 & 0.634 & 0.649 \\
\hline & WPT-AC/ethanol & 0.524 & 0.605 & 0.623 \\
\hline & Maxsorb-III/methanol & 0.601 & 0.661 & 0.665 \\
\hline & Maxsorb-III/ $\mathrm{CO}_{2}$ & 0.399 & 0.460 & 0.491 \\
\hline & Maxsorb-III/n-butane & 0.112 & 0.172 & 0.206 \\
\hline & Maxsorb-III/R-134a & 0.385 & 0.477 & 0.531 \\
\hline & SAC-2/R32 & 0.348 & 0.462 & 0.513 \\
\hline & Maxsorb-III/R507a & 0.352 & 0.448 & 0.506 \\
\hline
\end{tabular}




\section{References}

1. Nicol, J.F.; Humphreys, M.A. Adaptive thermal comfort and sustainable thermal standards for buildings. Energy Build. 2002, 34, 563-572. [CrossRef]

2. Noor, S.; Ashraf, H.; Sultan, M.; Khan, Z.M. Evaporative cooling options for building air-conditioning: A comprehensive study for climatic conditions of Multan (Pakistan). Energies 2020, 13, 3061. [CrossRef]

3. Omer, A.M. Energy, environment and sustainable development. Renew. Sustain. Energy Rev. 2008, 12, 2265-2300. [CrossRef]

4. Choudhury, B.; Chatterjee, P.K.; Sarkar, J.P. Review paper on solar-powered air-conditioning through adsorption route. Renew. Sustain. Energy Rev. 2010, 14, 2189-2195. [CrossRef]

5. Hamdy, M.; Askalany, A.A.; Harby, K.; Kora, N. An overview on adsorption cooling systems powered by waste heat from internal combustion engine. Renew. Sustain. Energy Rev. 2015, 51, 1223-1234. [CrossRef]

6. El-Sharkawy, I.I.; AbdelMeguid, H.; Saha, B.B. Potential application of solar powered adsorption cooling systems in the Middle East. Appl. Energy 2014, 126, 235-245. [CrossRef]

7. Hassan, H.Z.; Mohamad, A.A. A review on solar cold production through absorption technology. Renew. Sustain. Energy Rev. 2012, 16, 5331-5348. [CrossRef]

8. Kalkan, N.; Young, E.A.; Celiktas, A. Solar thermal air conditioning technology reducing the footprint of solar thermal air conditioning. Renew. Sustain. Energy Rev. 2012, 16, 6352-6383. [CrossRef]

9. Zhai, X.Q.; Qu, M.; Li, Y.; Wang, R.Z. A review for research and new design options of solar absorption cooling systems. Renew. Sustain. Energy Rev. 2011, 15, 4416-4423. [CrossRef]

10. Sultan, M.; El-Sharkawy, I.I.; Miyazaki, T.; Saha, B.B.; Koyama, S. An overview of solid desiccant dehumidification and air conditioning systems. Renew. Sustain. Energy Rev. 2015, 46, 16-29. [CrossRef]

11. Jani, D.B.; Mishra, M.; Sahoo, P.K. Solid desiccant air conditioning-A state of the art review. Renew. Sustain. Energy Rev. 2016, 60, 1451-1469. [CrossRef]

12. Ge, T.S.; Dai, Y.J.; Wang, R.Z. Review on solar powered rotary desiccant wheel cooling system. Renew. Sustain. Energy Rev. 2014, 39, 476-497. [CrossRef]

13. Zhai, X.Q.; Wang, R.Z. Experimental investigation and theoretical analysis of the solar adsorption cooling system in a green building. Appl. Therm. Eng. 2009, 29, 17-27. [CrossRef]

14. Sultan, M.; Miyazaki, T.; Saha, B.B.; Koyama, S. Steady-state investigation of water vapor adsorption for thermally driven adsorption based greenhouse air-conditioning system. Renew. Energy 2016, 86, 785-795. [CrossRef]

15. Jribi, S.; Miyazaki, T.; Saha, B.B.; Koyama, S.; Maeda, S.; Maruyama, T. CFD simulation and experimental validation of ethanol adsorption onto activated carbon packed heat exchanger. Int. J. Refrig. 2017, 74, 345-353. [CrossRef]

16. Sosnowski, M. Evaluation of heat transfer performance of a multi-disc sorption bed dedicated for adsorption cooling technology. Energies 2019, 12, 4660. [CrossRef]

17. Saha, B.B.; Koyama, S.; Kashiwagi, T.; Akisawa, A.; Ng, K.C.; Chua, H.T. Waste heat driven dual-mode, multi-stage, multi-bed regenerative adsorption system. Int. J. Refrig. 2003, 26, 749-757. [CrossRef]

18. Miyazaki, T.; Akisawa, A.; Saha, B.B. The performance analysis of a novel dual evaporator type three-bed adsorption chiller. Int. J. Refrig. 2010, 33, 276-285. [CrossRef]

19. Chorowski, M.; Pyrka, P.; Rogala, Z.; Czupryński, P. Experimental study of performance improvement of 3-Bed and 2-Evaporator adsorption chiller by control optimization. Energies 2019, 12, 3943. [CrossRef]

20. Alahmer, A.; Wang, X.; Alam, K.C.A. Dynamic and economic investigation of a solar thermal-driven two-bed adsorption chiller under Perth Climatic Conditions. Energies 2020, 13, 1005. [CrossRef]

21. Askalany, A.A.; Saha, B.B.; Kariya, K.; Ismail, I.M.; Salem, M.; Ali, A.H.H.; Morsy, M.G. Hybrid adsorption cooling systems-An overview. Renew. Sustain. Energy Rev. 2012, 16, 5787-5801. [CrossRef]

22. Vasta, S.; Palomba, V.; La Rosa, D.; Mittelbach, W. Adsorption-compression cascade cycles: An experimental study. Energy Convers. Manag. 2018, 156, 365-375. [CrossRef]

23. Lychnos, G.; Tamainot-Telto, Z. Prototype of hybrid refrigeration system using refrigerant R723. Appl. Therm. Eng. 2018, 134, 95-106. [CrossRef]

24. Roumpedakis, T.C.; Vasta, S.; Sapienza, A.; Kallis, G.; Karellas, S.; Wittstadt, U.; Tanne, M.; Harborth, N.; Sonnenfeld, U. Performance results of a solar adsorption cooling and heating unit. Energies 2020, 13, 1630. [CrossRef] 
25. Saha, B.B.; Akisawa, A.; Kashiwagi, T. Solar/waste heat driven two-stage adsorption chiller: The prototype. Renew. Energy 2001, 23, 93-101. [CrossRef]

26. Liu, Y.L.; Wang, R.Z.; Xia, Z.Z. Experimental performance of a silica gel-water adsorption chiller. Appl. Therm. Eng. 2005, 25, 359-375. [CrossRef]

27. Saha, B.B.; El-Sharkawy, I.I.; Thorpe, R.; Critoph, R.E. Accurate adsorption isotherms of R134a onto activated carbons for cooling and freezing applications. Int. J. Refrig. 2012, 35, 499-505. [CrossRef]

28. Habib, K.; Saha, B.B.; Rahman, K.A.; Chakraborty, A.; Koyama, S.; Ng, K.C. Experimental study on adsorption kinetics of activated carbon/R134a and activated carbon/R507A pairs. Int. J. Refrig. 2010, 33, 706-713. [CrossRef]

29. El-Sharkawy, I.I.; Saha, B.B.; Koyama, S.; He, J.; Ng, K.C.; Yap, C. Experimental investigation on activated carbon-ethanol pair for solar powered adsorption cooling applications. Int. J. Refrig. 2008, 31, 1407-1413. [CrossRef]

30. Qasem, N.A.A.; El-Shaarawi, M.A.I. Improving ice productivity and performance for an activated carbon/methanol solar adsorption ice-maker. Sol. Energy 2013, 98, 523-542. [CrossRef]

31. Rafique, M.M. Evaluation of metal-organic frameworks as potential adsorbents for solar cooling applications. Appl. Syst. Innov. 2020, 3, 26. [CrossRef]

32. Sultan, M.; El-Sharkawy, I.I.; Miyazaki, T.; Saha, B.B.; Koyama, S.; Maruyama, T.; Maeda, S.; Nakamura, T. Insights of water vapor sorption onto polymer based sorbents. Adsorption 2015, 21, 205-215. [CrossRef]

33. Sultan, M.; El-Sharkawy, I.I.; Miyazaki, T.; Saha, B.B.; Koyama, S.; Maruyama, T.; Maeda, S.; Nakamura, T. Water vapor sorption kinetics of polymer based sorbents: Theory and experiments. Appl. Therm. Eng. 2016, 106, 192-202. [CrossRef]

34. Zhao, H.; Jia, S.; Cheng, J.; Tang, X.; Zhang, M.; Yan, H.; Ai, W. Experimental Investigations of Composite Adsorbent 13X/CaCl2 on an Adsorption Cooling System. Appl. Sci. 2017, 7, 620. [CrossRef]

35. Alghoul, M.A.; Sulaiman, M.Y.; Azmi, B.Z.; Wahab, M. Abd. Advances on multi-purpose solar adsorption systems for domestic refrigeration and water heating. Appl. Therm. Eng. 2007, 27, 813-822. [CrossRef]

36. Hastürk, E.; Ernst, S.-J.; Janiak, C. Recent advances in adsorption heat transformation focusing on the development of adsorbent materials. Curr. Opin. Chem. Eng. 2019, 24, 26-36. [CrossRef]

37. Edin Hamrahi, S.; Goudarzi, K.; Yaghoubi, M. Experimental study of the performance of a continues solar adsorption chiller using Nano-activated carbon/methanol as working pair. Sol. Energy 2018, 173, 920-927. [CrossRef]

38. Ghazy, M.; Askalany, A.A.; Saha, B.B. Maxsorb III/HFC404A as an adsorption pair for renewable energy driven systems. Int. J. Refrig. 2020. [CrossRef]

39. Manila, M.R.; Mitra, S.; Dutta, P. Studies on dynamics of two-stage air cooled water/silica gel adsorption system. Appl. Therm. Eng. 2020, 178, 115552. [CrossRef]

40. Pan, Q.W.; Wang, R.Z. Study on operation strategy of a silica gel-water adsorption chiller in solar cooling application. Sol. Energy 2018, 172, 24-31. [CrossRef]

41. Solovyeva, M.V.; Gordeeva, L.G.; Krieger, T.A.; Aristov, Y.I. MOF-801 as a promising material for adsorption cooling: Equilibrium and dynamics of water adsorption. Energy Convers. Manag. 2018, 174, $356-363$. [CrossRef]

42. Ntep, T.J.M.M.; Reinsch, H.; Hügenell, P.P.C.; Ernst, S.-J.; Hastürk, E.; Janiak, C. Designing a new aluminium muconate metal-organic framework (MIL-53-muc) as a methanol adsorbent for sub-zero temperature heat transformation applications. J. Mater. Chem. A 2019, 7, 24973-24981. [CrossRef]

43. Pal, A.; Uddin, K.; Thu, K.; Saha, B.B. Activated carbon and graphene nanoplatelets based novel composite for performance enhancement of adsorption cooling cycle. Energy Convers. Manag. 2019, 180, 134-148. [CrossRef]

44. Younes, M.M.; El-Sharkawy, I.I.; Kabeel, A.E.; Uddin, K.; Miyazaki, T.; Saha, B.B. Characterization of silica gel-based composites for adsorption cooling applications. Int. J. Refrig. 2020, 118, 345-353. [CrossRef]

45. Shabir, F.; Sultan, M.; Miyazaki, T.; Saha, B.B.; Askalany, A.; Ali, I.; Zhou, Y.; Ahmad, R.; Shamshiri, R.R. Recent updates on the adsorption capacities of adsorbent-adsorbate pairs for heat transformation applications. Renew. Sustain. Energy Rev. 2020, 119. [CrossRef]

46. El-Sharkawy, I.I.; Uddin, K.; Miyazaki, T.; Baran Saha, B.; Koyama, S.; Kil, H.S.; Yoon, S.H.; Miyawaki, J. Adsorption of ethanol onto phenol resin based adsorbents for developing next generation cooling systems. Int. J. Heat Mass Transf. 2015, 81, 171-178. [CrossRef] 
47. Pal, A.; Thu, K.; Mitra, S.; El-Sharkawy, I.I.; Saha, B.B.; Kil, H.S.; Yoon, S.H.; Miyawaki, J. Study on biomass derived activated carbons for adsorptive heat pump application. Int. J. Heat Mass Transf. 2017, 110, 7-19. [CrossRef]

48. El-Sharkawy, I.I.; Hassan, M.; Saha, B.B.; Koyama, S.; Nasr, M.M. Study on adsorption of methanol onto carbon based adsorbents. Int. J. Refrig. 2009, 32, 1579-1586. [CrossRef]

49. Jribi, S.; Miyazaki, T.; Saha, B.B.; Pal, A.; Younes, M.M.; Koyama, S.; Maalej, A. Equilibrium and kinetics of CO2 adsorption onto activated carbon. Int. J. Heat Mass Transf. 2017, 108, 1941-1946. [CrossRef]

50. Saha, B.B.; Chakraborty, A.; Koyama, S.; Yoon, S.H.; Mochida, I.; Kumja, M.; Yap, C.; Ng, K.C. Isotherms and thermodynamics for the adsorption of n-butane on pitch based activated carbon. Int. J. Heat Mass Transf. 2008, 51, 1582-1589. [CrossRef]

51. Loh, W.S.; Ismail, A.B.; Xi, B.; Ng, K.C.; Chun, W.G. Adsorption isotherms and isosteric enthalpy of adsorption for assorted refrigerants on activated carbons. J. Chem. Eng. Data 2012, 57, 2766-2773. [CrossRef]

52. Sultan, M.; Miyazaki, T.; Saha, B.B.; Koyama, S.; Kil, H.-S.; Nakabayashi, K.; Miyawaki, J.; Yoon, S.-H. Adsorption of Difluoromethane (HFC-32) onto phenol resin based adsorbent: Theory and experiments. Int. J. Heat Mass Transf. 2018, 127, 348-356. [CrossRef]

53. Dubinin, M.M. Adsorption in micropores. J. Colloid Interface Sci. 1967, 23, 487-499. [CrossRef]

54. Dubinin, M.M.; Astakhov, V.A. Development of the concepts of volume filling of micropores in the adsorption of gases and vapors by microporous adsorbents. Russ. Chem Bull. 1971, 20, 8-12. [CrossRef]

55. Dubinin, M.M.; Radushkevich, L.V. Evaluation of microporous materials with a new isotherm. Dokl. Akad. Nauk. SSSR 1947, 55, 331-334.

56. Amankwah, K.A.G.; Schwarz, J.A. A modified approach for estimating pseudo-vapor pressures in the application of the Dubinin-Astakhov equation. Carbon 1995, 33, 1313-1319. [CrossRef]

57. Uddin, K.; Islam, M.A.; Mitra, S.; Lee, J.; Thu, K.; Saha, B.B.; Koyama, S. Specific heat capacities of carbon-based adsorbents for adsorption heat pump application. Appl. Therm. Eng. 2018, 129, 117-126. [CrossRef]

58. Islam, M.A.; Rocky, K.A.; Pal, A.; Thu, K.; Saha, B.B. Specific heat capacity measurement of mangrove and waste palm trunk in raw, carbonized and activated form. In Proceedings of the IMPRES 2019, Kanazawa, Japan, 20-23 October 2019.

59. Askalany, A.A.; Saha, B.B. Towards an accurate estimation of the isosteric heat of adsorption-A correlation with the potential theory. J. Colloid Interface Sci. 2017, 490, 59-63. [CrossRef] 